\title{
STRUCTURAL AND MORPHOLOGICAL FEATURES OF Piaractus mesopotamicus (HOLMBERG, 1887) GILLS
}

\author{
SEVERI, W., ${ }^{1}$ RANTIN, F. T. ${ }^{2}$ and FERNANDES, M. N. ${ }^{2}$ \\ ${ }^{1}$ Departamento de Pesca, Universidade Federal Rural de Pernambuco, Av. Dom Manuel de Medeiros, 68, CEP \\ 52171-900, Recife, PE, Brazil \\ ${ }^{2}$ Departamento de Ciências Fisiológicas, Universidade Federal de São Carlos, C.P. 676, CEP 13565-905, São \\ Carlos, SP, Brazil \\ Correspondence to: William Severi, Departamento de Pesca, Universidade Federal Rural de Pernambuco, Av. Dom \\ Manuel de Medeiros, 68, CEP 52171-900, Recife, PE, Brazil, e-mail: wseveri@ truenet.com.br \\ Received April 28, 1999 - Accepted July 26, 1999 - Distributed May 31, 2000
}

(With 6 figures)

\begin{abstract}
The pacu Piaractus mesopotamicus (Holmberg, 1887), is a commercially important serrasalmid fish endemic to the Paraná-Paraguay River basin, and one of the most widely cultivated native fish species in the Neotropics. As a migratory species, also inhabiting temporary pools subjected to hypoxic conditions, the species presents a high plasticity concerning respiratory adaptations. In order to supplement basic knowledge on the respiratory physiology and morphology of this species, some structural features of pacu gills, such as filament and lamellae structure, and circulatory pattern are described in this paper.
\end{abstract}

Key words: gill structure, gill morphology, pacu, Piaractus mesopotamicus.

\section{RESUMO}

\section{Aspectos estruturais e morfológicos das lerânquias de Piaractus mesopotamicus} (Holmberg, 1887)

O pacu, Piaractus mesopotamicus (Holmberg, 1887), um serrasalmídeo de importância comercial endêmico da bacia do Paraná-Paraguai, é uma das espécies de peixe mais amplamente cultivadas na região Neotropical. Sendo uma espécie migradora, que também habita ambientes temporários sujeitos a condições hipóxicas, apresenta grande plasticidade em suas adaptações respiratórias. Com a finalidade de complementar o conhecimento sobre a fisiologia e morfologia respiratória da espécie, alguns aspectos morfológicos das brânquias do pacu, como a estrutura de filamentos e lamelas e o padrão circulatório, são descritos neste trabalho.

Palavras-chave: estrutura branquial, morfologia branquial, pacu, Piaractus mesopotamicus.

\section{INTRODUCTION}

The pacu, Piaractus mesopotamicus (Holmberg, 1887), a commercially important serrasalmid fish endemic to the Paraná-Paraguay River basin, is currently one of the most widely cultivated native fish species in the Neotropical region, and its potential for aquaculture has long been recognized by several authors (Godoy, 1975; LoweMcConnell, 1984; Saint-Paul, 1986).
Environmental conditions in fish ponds may be extremely stressful for cultivated species, particularly in the tropics, owing to daily and seasonal dissolved oxygen fluctuations, which may lead to severe hypoxia or even temporary anoxia, notedly under semi-intensive culture systems (Boyd, 1984). Such variations may have a deleterious effect on feeding or reproduction, and lead to nutritional deficiencies, metabolic alterations and diseases. 
The ability of any fish species to overcome such environmental constraints is closely related to its respiratory strategy, whether unimodal or bimodal (Kramer, 1983), which in turn depends on gill morphology and morphometrics, respiratory physiology, as well as other physiological, biochemical and behavioural aspects (Braum \& Junk, 1982; Saint-Paul \& Soares, 1987; Kramer, 1988).

Saint-Paul \& Bernardino (1988) first recorded the use of aquatic surface respiration (ASR) by P. mesopotamicus, while the cardiorespiratory responses to ASR were analysed by Rantin \& Kalinin (1996) and Rantin et al. (1998). Severi et al. (1997) characterised the gill morphometry of the species, and Kalinin et al. (in press) studied the relationship between ventilatory flow and buccal and opercular volumes of $P$. mesopotamicus during normoxia and graded hypoxia. In order to supplement basic knowledge on the respiratory physiology and morphology of this species, some structural features of pacu gills are described in this paper.

\section{MATERIAL AND METHODS}

Right side gill arches were removed from 23 fish (ranging in weight from 13.4 to $1,470 \mathrm{~g}$ ), previously anesthetized in benzocaine $(0.01 \%)$, and fixed in ALFAC (80\% Ethanol - 85\%, formaldehyde $-10 \%$, and glacial acetic acid $-5 \%$ ) for 24 hours, followed by 12 to 24 hours-period of tapwater wash-out, depending on specimen size. All arches were then stored in 70\% Ethanol prior to analysis.

The analysis of filament structures, such as lamellae shape and dimensions, circulatory system and muscles, was done according to the methodology proposed by Hughes (1984). Samples of the base, middle and tip of the second branchial arch filaments were dehydrated in ethanol series, embedded in wax and serial sections $(5 \mathrm{~mm})$ from longitudinal, transverse and saggital of the gill filaments were stained with haematoxylin-eosin (as per Beçak \& Paulete, 1970), and analyzed under light microscopy.

\section{RESULTS}

The pacu presents a branchial apparatus composed of four gill arches, with long and numerous filaments, disposed inside a laterally compressed opercular cavity. The gill filaments are located on the posterior portion of the epibranchial and ceratobranchial bones, and disposed in two rows along the arch length, forming the so-called anterior (oral) and posterior (aboral) hemibranches, both of which constitute the holobranch (Harder, 1975). These elements extend out of the bony structure, along the tegument and project into the cranial and mandibular insertion of the gill arches. This tegument is longer in arches III and IV than I and II (Fig. 1).

The filaments are long and numerous, and their free portion from the interbranchial septum (is) averages $60 \%$ of the total filament length.

In arches I and II, longer filaments are located in the epibranchial median region, while those in arches III and IV are located in the median ceratobranchial region. The joint region between branchial bones corresponds to the arch curvature where shorter filaments in all arches are found (Fig. 1). The average filament length decreases from arch I to IV, both in the epibranchial and ceratobranchial bones, as seen in Fig. 2.

The secondary lamellae (sl) are perpendicularly distributed along the whole superior and inferior filament surfaces, being also found at the region between filament insertion on the arch (Fig. 3). Lamellae dimensions vary along the filament, with the base breadth being always shorter than filament width. The dominant lamellae shape is rectangular (Figs. 4B and 5C), but triangular ones are also located near the filament tip (Figs. 4A and 5D).

Some circulatory and structural details along a transversal view of a pacu holobranch are depicted in Fig. 5. The afferent branchial artery (aba) leads to the afferent artery (aa), which runs along the gill arch and extends into afferent primary arteries $\left(\mathrm{aa}_{1}\right)$ at the base of the filaments (Fig. 5A). These are distributed along the filament and far from the lamellae base through all the septum region. The afferent primary arteries $\left(\mathrm{aa}_{1}\right)$ originate from the afferent artery into ramifications leading to one or more lamellae (Figs. 5B and 6). The efferent branchial artery (eba) is more internal to the arch, and drains the arterial blood from the efferent artery (ea) placed at the outer filament portion and along the secondary lamellae external base (Fig. 5A). 

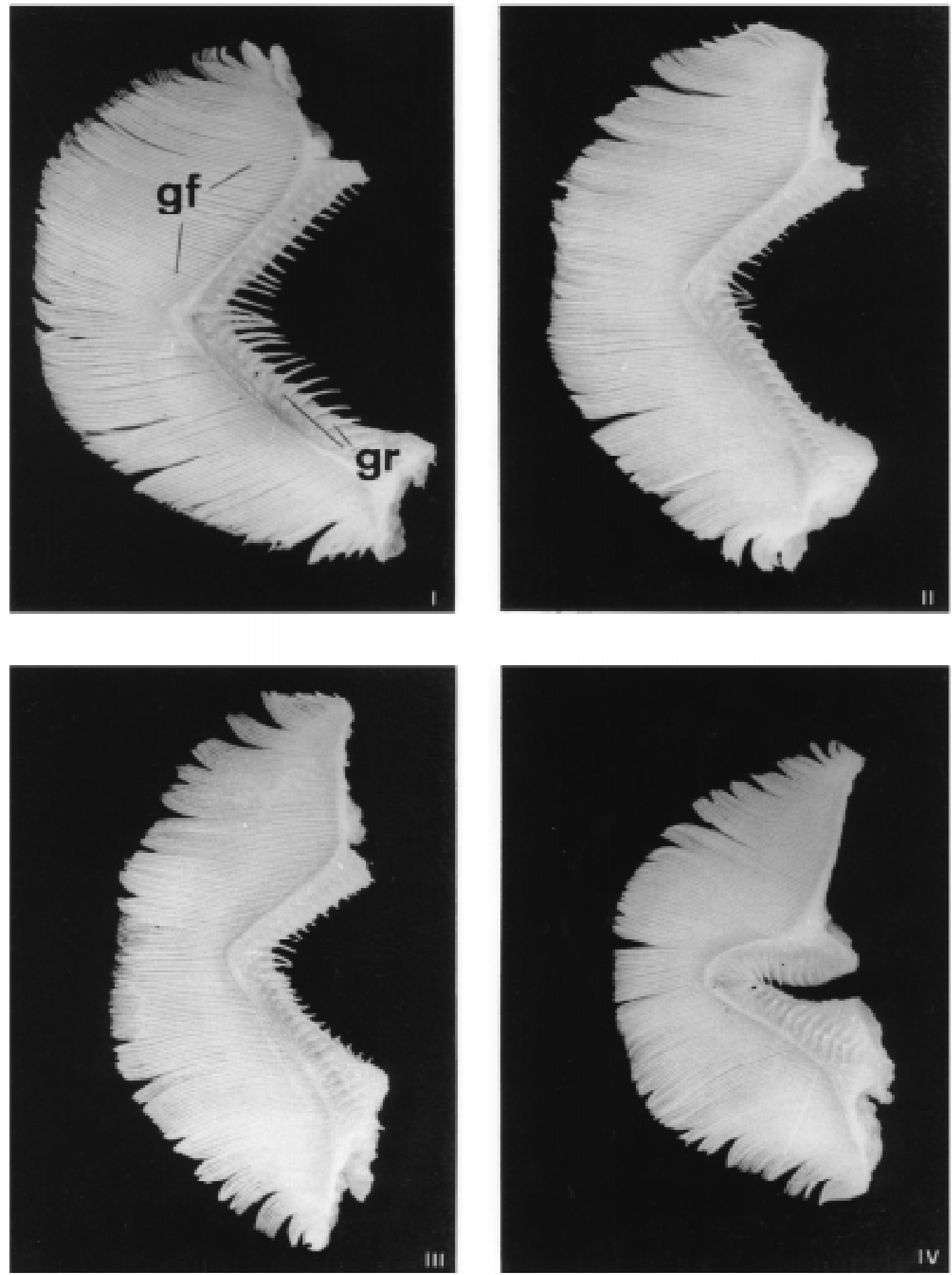

Fig. 1 - Anterior view of Piaractus mesopotamicus branchial arches (arches I to IV; gr - gill rakers; gf - gill filaments). 


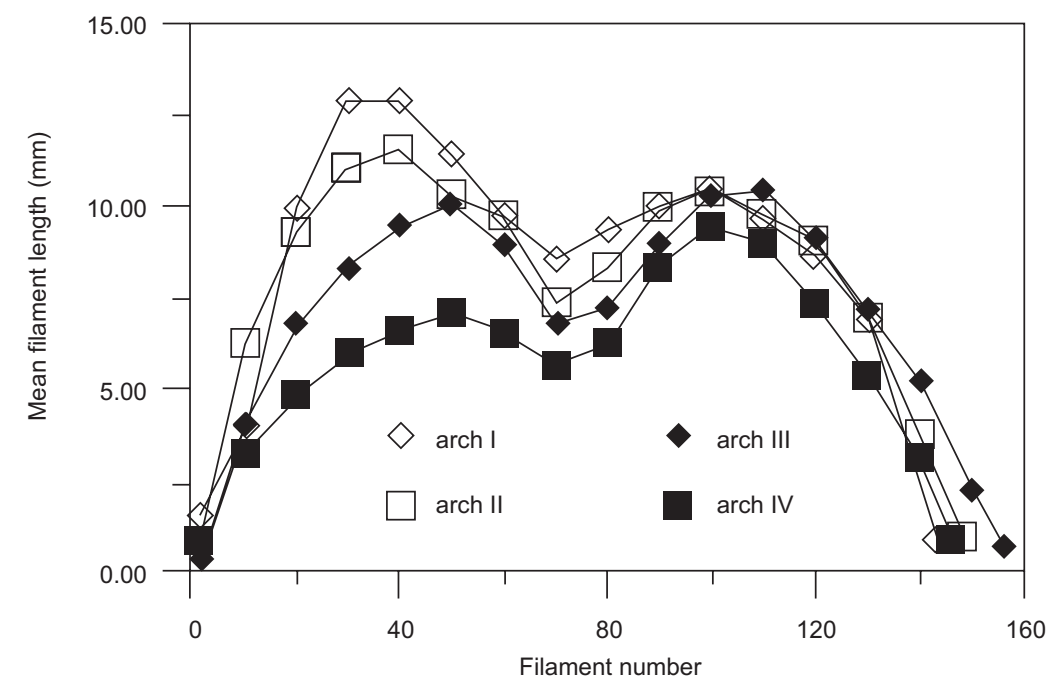

Fig. 2 - Diagram showing variation in filament average length of the four arches of Piaractus mesopotamicus $\left(\mathrm{W}_{\mathrm{t}}=171\right.$ g).

The epibranchial and ceratobranchial are placed at the anterior-lateral side of the arch. The branchial rays (br) stretch into the filaments almost to its end, and present undulations on its outer side, similar to spines, which cover up to half the free portion of the filament (Fig. 5E).

The gill-filament muscles are comprised of adductor muscles located on each hemibranch, crossing at the septum, and abductor ones located between the branchial ray base and the filamentsupporting bone (Fig. 5E).

\section{DISCUSSION}

The anatomical structure of pacu gills is similar to other teleost fish. The branchial filaments are disposed in four branchial arches (I to IV), a common feature in characins, whose gills are composed of five arches, the last one when present, being modified into a pharingeal plate (Weitzman, 1962). These arches correspond to the viscerocranium cephalic arches 3 to 6 (Harder, 1975). The filaments length along the different arches is variable, as well as the anterior and posterior hemibranches length.

Such characteristics have been observed in other species (Hughes, 1972; Burggren et al., 1979; Fernandes \& Rantin, 1985, 1986). The associated variabilities were considered to be inter and intraspecific by Harder (1975), dependent on spatial relations in the fish head, leading to different shapes: i.e. long or short, laterally or dorso-ventrally compressed. Similarly, Galis \& Barel (1980) studied some morpho-functional aspects of gills among several cichlids, and considered the filament number and length as morpho-plastic features, and an adaptation to the esterno-hyoid muscle shape, which is related to the buccal cavity and outer head shape.

The laterally-compressed body of P. mesopotamicus has favoured the development of long filaments, with an average length of $1.38 \mathrm{~mm}$ for a $1 \mathrm{~g}$ fish (Severi, 1991). The difference found in average filament length, as well as in filament number per $\mathrm{mm}$ of filament length along the different arches, may be related to the head morpho-anatomical characteristics and to the oxygen absorption control (see below).

Differences on the participation of different branchial arches in the total filament number and length have been demonstrated among cichlids by Galis \& Barel (1980). Greater participations for arches I and II on the composition of such parameters were determined for Haplochromis macrognathus, $H$. pharyngomylus and $H$. schubotzi, in a similar manner as shown for P. mesopotamicus. 


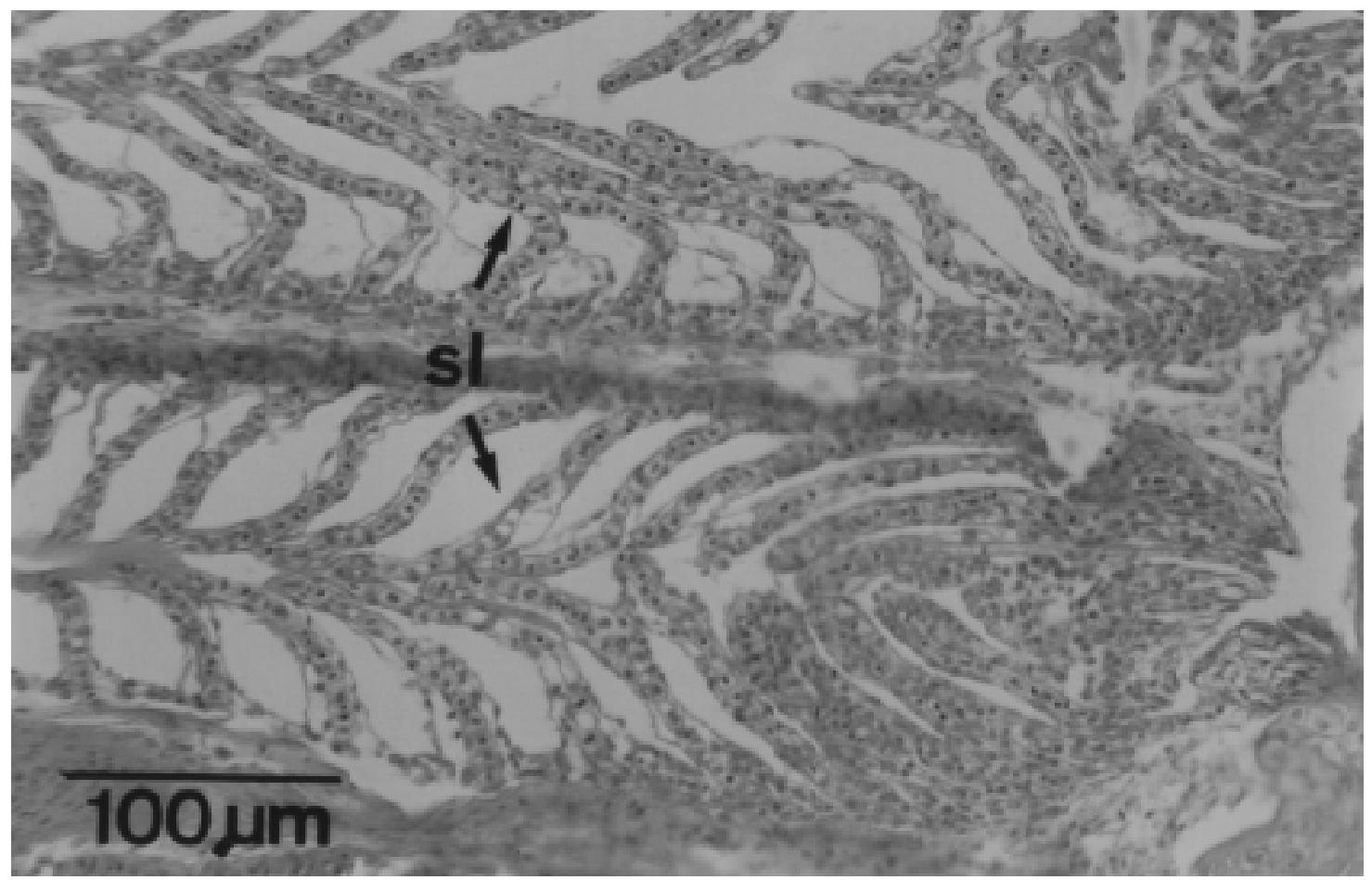

Fig. 3 - Insertion of secondary lamellae (sl) at the base of adjacent filaments in Piaractus mesopotamicus gills.

Teleost gills are formed from the endodermal tissue around the branchial skeleton, composed of hypo-, cerato-, epi- and pharyngobranchial bones (Bertin, 1958; Harder, 1975). The filaments of $P$. mesopotamicus are mainly distributed along the epi- and ceratobranchial, the other bones being markedly reduced. The extension of filaments out of the bony structure and into the cranial and mandibular insertions, as observed in this species, may be a function of its compressed head and small space available for filament distribution. The branchial rays located internally to the filaments are responsible for its support, and present some lateral propagations which might also provide tissue support.

The interbranchial septum is reduced in the pacu, similar to other teleosts, and in contrast to those presented by elasmobranchs (Goodrich, 1958). This feature, together with the action of abductor and adductor muscles, and a developed branchial ray, allow filaments to be maintained in a favourable position for gaseous exchanges (Harder, 1975).

The position of the gill-filament muscles in the pacu is similar to type I described by Hughes
\& Morgan (1973), in which the adductor muscle originates on the basal end of two successive gill rays, being inserted on the gill ray of the filament of the opposite hemibranch. The two muscles, therefore, cross on the intermediary septum region. The abductor muscles are located on the anterior end of the gill arch, and join the oral end of its cartilage to the terminal end of the gill ray.

The water flow through the different filament portion (basal, median and apical) varies according to the respiratory cycle phase and the ventilatory volume.

Under moderate ventilation there is a great resistance to flow at the filament tip, directing water to flow mainly through base and median lamellae. Those lamellae on the septum region, which are more densely disposed, present longer length and greater bilateral area, therefore presenting a greater resistance to water flow and probably increasing diffusion at this region.

The functioning system, according to the animal's metabolic demand, is made possible by nervous and muscular control of filaments, which permit their movement (Hughes \& Shelton, 1962). 


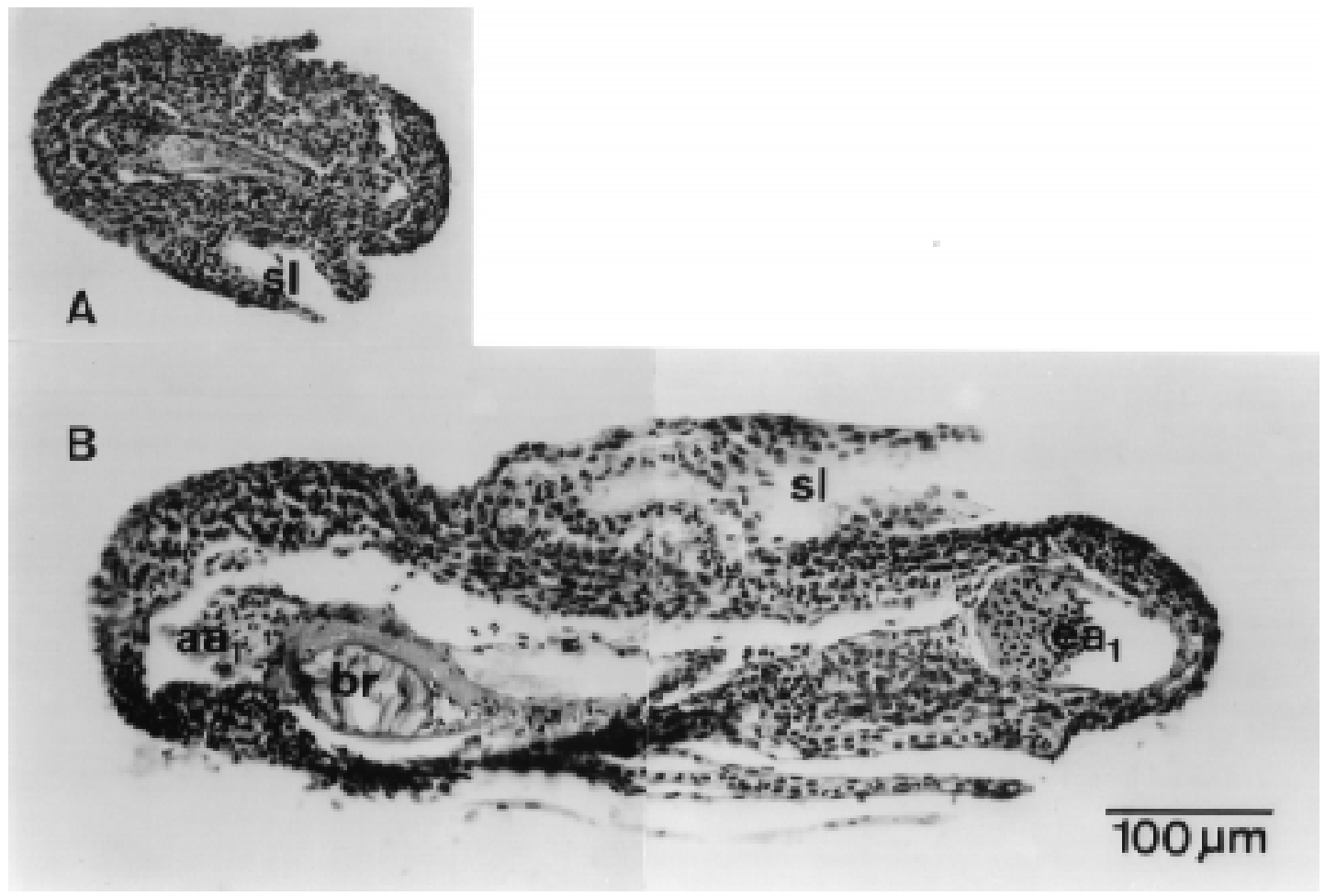

Fig. 4 - Semi-thin cross-section of a primary lamellae of Piaractus mesopotamicus, showing the shape of secondary lamellae (sl) at: (A) filament's tip and (B) median region. Note the disposition of the branchial ray (br), afferent primary artery (aa $)_{1}$ and efferent primary artery $\left(\mathrm{ea}_{1}\right)$.

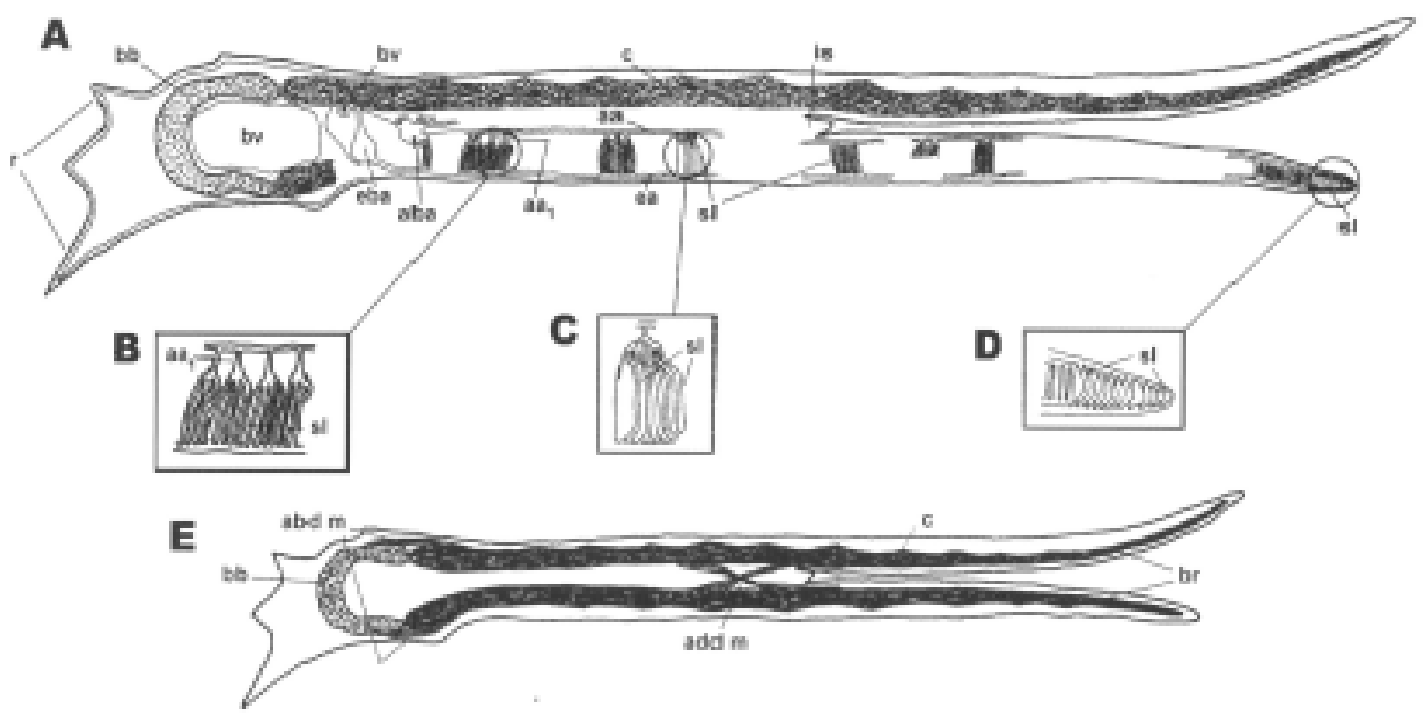

Fig. 5 - (A) Schema of the gill vasculature of Piaractus mesopotamicus (aa. afferent artery; aa1. afferent primary artery; aba. afferent branchial artery; bb. branchial bone; bv. branchial vein; c. cartilage; ea. efferent artery; eba. efferent branchial artery; is. interbranchial septum; sl. secondary lamellae); (B) detail of afferent primary arteries; details of secondary lamellae at filament (C) median and (D) terminal region; and (E) schema of filament musculature (abd m. abductor muscle; add m. adductor muscle; br. branchial ray). 


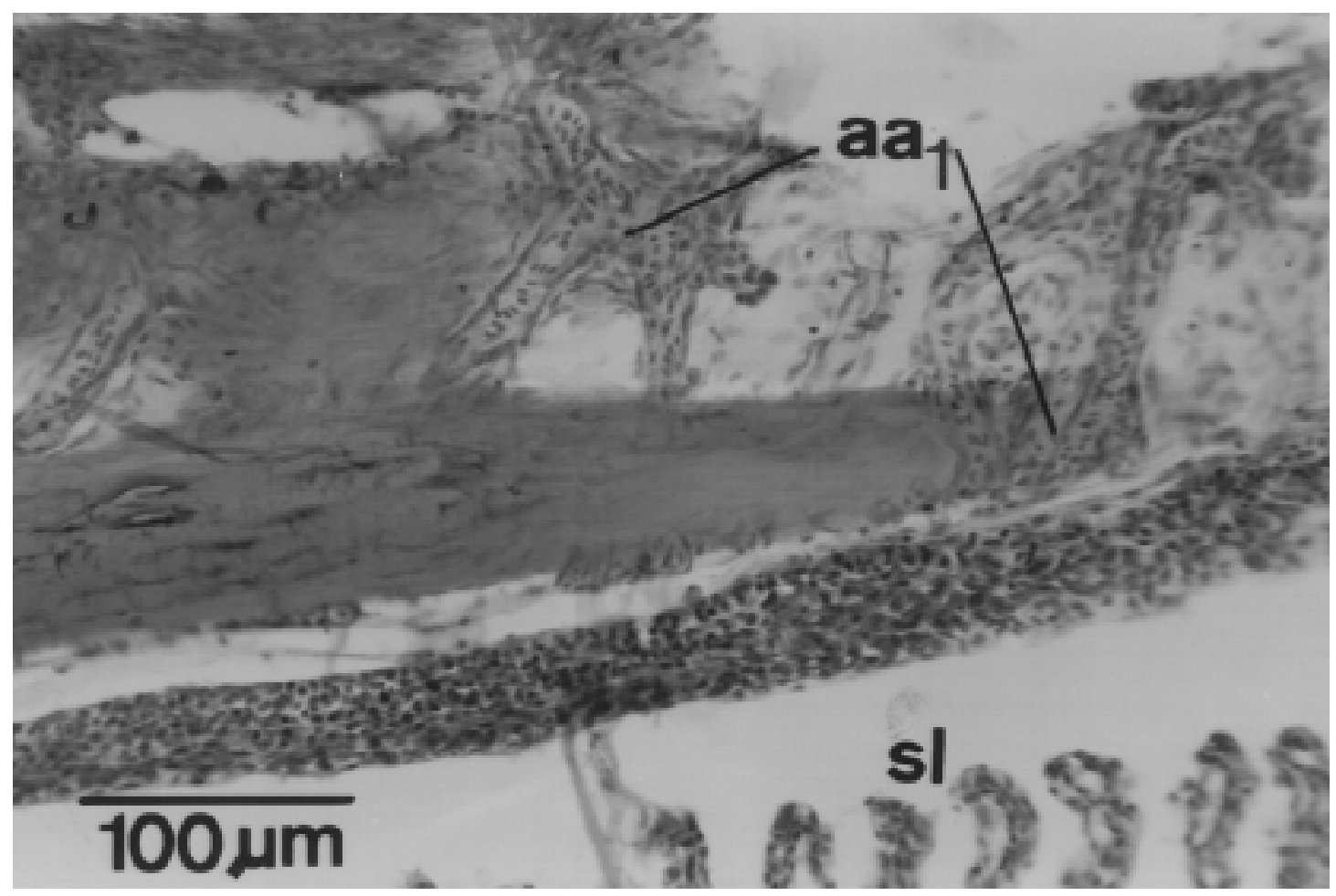

Fig. 6 - Longitudinal section of Piaractus mesopotamicus filament, showing the ramification of afferent artery into afferent primary arteries $\left(\mathrm{aa}_{1}\right)$ at the interbranchial septum.

As ventilation increases, there is a lamellae recruitment, mainly from the filament extremities, which are not used under moderate ventilation (Hughes, 1972). The long filaments of P. mesopotamicus, mostly free from the septum, and assisted by its muscles, make it possible to maintain the filaments of adjacent arches into a distended position, thus offering more resistance to water flow, effectively increasing diffusion. This mechanism may be beneficial during intense swimming activity (e.g. migration of the species in its natural environment).

The secondary lamellae appears to present considerable variation in shape along the filament and may constitute a species-specific characteristic (Hughes, 1970, 1984; Hughes \& Morgan, 1973). For example, those located near the filament tip tend to be shorter and higher, than those from the base which are normally more rectangular (Hughes, 1972). Some striking differences may be found in some species, such as among Scombriformes, whose gills possess fusion between lamellae from adjacent filaments in several genuses (Muir \& Kendall, 1968; Muir, 1969).

According to Harder (1975), new lamellae in teleosts are formed at the tip of the filaments, with older ones located at its base. In the pacu, triangular lamellae are present at the apical portion of the filaments, and rectangular ones along the rest of it. Based on Harder's assertion, the lamellae seem to change their shape as the length of filaments increases during the ontogenic development, thus taking a rectangular shape as its base broadens to fit the filament base broadening at its intermediary portions.

The arterio-arterial system of $P$. mesopotamicus gills show a configuration similar to the cypriniform type described by Harder (1975). The arterioles ramifications found at the septum region must have some relevant role on the control of secondary lamellae recruitment under a greater oxygen demand (Harder, 1975; Hughes \& Morgan, 1973). 
The secondary lamellae of the pacu present several capillaries formed by pillar cells and epithelial tissue, and a marginal channel at the lamellae border. The possible role of such channel as a blood shunt between afferent and efferent arteries is controversial (Harder, 1975; Hughes \& Morgan, 1973). The contractile feature of the pillar cells allows the microcirculation pattern to change and vary the distance for oxygen diffusion, thus modifying the blood flow distribution through the lamellae (Hughes \& Morgan, 1973; Hughes, 1982).

Variation in the dimensions of capillaries and water-blood barrier as a function of blood pressure differences were observed for lingcod Ophiodon elongatus by Farrell et al. (1980). This shows the capacity of regulation of the blood flow and the diffusion quotient at the lamellae level. Muir \& Brown (1971, in Hughes \& Morgan, 1973) showed that some teleosts present an increase in lamellar "channels" diameter with the increase of lamellae length, as a consequence of the animal's growth, thus compensating for a drop in the blood pression through the gills. Such control is possibly also mediated by the action of $\mathrm{O}_{2}$ chemoreceptors, which seem to screen both water and arterial blood (Milsom, 1993), and are responsible for gill ventilation and overall respiratory homeostasis.

P. mesopotamicus gills present some typical features of migratory species, such as long filaments and high lamellae density, but a comparatively reduced respiratory gill surface, which indicate an adaptation to its head shape and available space for filament distribution (Severi et al., 1997). The coupling of such characteristics seem to suit the oxygen demand under intense swimming in turbulent normoxic waters in its natural environment. However, under hypoxic conditions the species present a high critical oxygen tension $\left(\mathrm{PcO}_{2}\right)$, as determined by Rantin et al. (1998), compensated by the use of ASR. The inability to increase its ventilation volume under hypoxia, corresponding to $93.2 \%$ of buccal and $94.9 \%$ of opercular volumes, is limited by the morphology of the opercular chamber (Kalinin et al., in press). Such characteristics indicate a considerable flexibility concerning the respiratory metabolism of $P$. mesopotamicus, and the combination of different adaptative strategies for this exclusive water-breathing fish species.

Acknowledgments - We thank the Centro de Pesquisa em Aquicultura Ambiental - IAP, state of Paraná, and the Centro de Pesquisa e Treinamento em Aquicultura - IBAMA, state of São Paulo, for providing the animals used in the study. CNPq and CAPES are acknowledged for financial support. Drs. Matthew Broadhurst and Vera Vieira kindly reviewed the manuscript and made valuable suggestions.

\section{REFERENCES}

BEÇAK, W. \& PAULETE, J., 1970, Técnicas de citologia e histologia. 1르. ed., Nobel, São Paulo, 470p.

BERTIN, L., 1958, Organes de la respiration aquatique, pp. 1303-1341. In: P.- P. Grassé, Traité de zoologie. Anatomie, systématique, biologie, Tome XIII, Agnathes et poissons, Masson, Paris.

BOYD, C. E., 1984, Water quality management for pond fish culture. Elsevier, Amsterdam, 318p.

BRAUM, E. \& JUNK, W. J., 1982, Morphological adaptations in two Amazonian characoids (Pisces) for surviving in oxygen deficient waters. Int. Ver. Gesamten Hydrobiol., 67(6): 869-886.

BURGGREN, W., DUNN, J. \& BARNARD, K., 1979, Branchial circulation and gill morphometrics in the sturgeon Acipenser transmontanus, an ancient Chondrosteian fish. Can. J. Zool., 57: 2160-2170.

FARRELL, A. P., SOBIN, S. S., RANDALL, D. J. \& CROSBY, S., 1980, Intralamellar blood flow pattern in fish gills. Am. J. Physiol., 239: R428-R426.

FERNANDES, M. N. \& RANTIN, F. T., 1985, Gill morphometry of the teleost Hoplias malabaricus (Bloch). Bol. Fisiol. Anim., Univ. S. Paulo, 1985(9): 57-65.

FERNANDES, M. N. \& RANTIN, F. T., 1986, Gill morphometry of cichlid fish, Oreochromis (Sarotherodon) niloticus (Pisces, Teleostei). Ciênc. Cult., 38(1): 192-198.

GALIS, F. \& BAREL, C. D. N., 1980, Comparative functional morphology of the gills of African lacustrine Cichlidae (Pisces, Teleostei). An eco-morphological approach. Neth. J. Zool., 30(2): 392-430.

GODOY, M. P., 1975, Peixes do Brasil: subordem Characoidei. Bacia do rio Mogi-Guaçu. Franciscana, Piracicaba, 2ํㅡ., vol. 217-397.

GOODRICH, E. S., 1958, Visceral clefts and gills, pp. 486510. In: E. S. Goodrich (ed.), Studies on the structure and development of vertebrates, vol. 2, Dover, New York.

HARDER, W., 1975, The respiratory organs, pp. 287-305. In: W. Harder, Anatomy of fishes. Schweizerbart'sche verlangsbuchhandlung, Stuttgart.

HUGHES, G. M., 1970, Morphological measurements of the gills of fishes in relation to their respiratory function. Folia Morphol., 18(2): 78-95.

HUGHES, G. M., 1972, Morphometrics of fish gills. Respir. Physiol., 14(1/2): 1-25.

HUGHES, G. M., 1982, An introduction to the study of gills, pp. 1-24. In: D. F. Houlihan, J. C. Rankin \& T. J. Shuttleworth (eds.), Gills. Cambridge univ. Press, Cambridge.

HUGHES, G. M., 1984, Measurement of gill area in fishes: practice and problems. J. Mar. Biol. Assoc. U. K., 64: 637-655. 
HUGHES, G. M. \& MORGAN, M., 1973, The structure of fish gills in relation to their respiratory function. Biol. Rev. Camb. Philos. Soc., 48: 419-475.

HUGHES, G. M. \& SHELTON, G., 1962, Respiratory mechanisms and their nervous control in fish, pp. 275364. In: O. Lowestein (ed.), Comparative physiology and biochemistry. Academic Press, London.

KALININ, A. L., SEVERI, W., GUERRA, C. D. R., COSTA, M. J. \& RANTIN, F. T. (in press), Ventilatory flow relative to intrabuccal and intraopercular volumes in the serrasalmid fish Piaractus mesopotamicus during normoxia and exposed to graded hypoxia. Rev. Brasil. Biol.

KRAMER, D. L., 1983, Aquatic surface respiration in the fishes of Panama: distribution in relation to risk of hypoxia. Environ. Biol. Fishes, 8(1): 49-54.

KRAMER, D. L., 1988, The behavioural ecology of air breathing by aquatic animals. Can. J. Zool., 66: 89-94.

LOWE-McCONNELL, R. H., 1984, The status of studies of South American freshwater food fishes, pp. 139-156. In: T. M. Zaret (ed.), Evolutionary ecology of neotropical freshwater fishes. Dr. W. Junk, The Hague.

MILSOM, W. K., 1993, Afferent inputs regulating ventilation in vertebrates, pp. 94-105. In: J. E. P. W. Bicudo (ed.), The vertebrate gas transport cascade. Adaptations and mode of life, CRC Press, Boca Raton.

MUIR, B. S., 1969, Further observations on gill modifications of oceanic fishes. Copeia, 1969(3): 629.

MUIR. B. S. \& KENDALL, J. I., 1968, Structural modifications in the gills of tunas and some other oceanic fishes. Copeia, 1968(2): 388-398.
RANTIN, F. T. \& KALININ, A. L., 1996, Aquatic surface respiration (ASR) and cardiorespiratory responses of Piaractus mesopotamicus (Teleostei, Serrasalmidae), during graded and acute hypoxia, pp. 59-67. In: A. L. Val, D. J. Randall \& D. MacKinley (eds.), The Physiology of Tropical Fish Symposium Proceedings, American Fisheries Society, San Francisco.

RANTIN, F. T., GUERRA, C. D. R., KALININ, A. L. \& GLASS, M. L., 1998, The influence of aquatic surface respiration (ASR) on cardio-respiratory function of the serrasalmid fish Piaractus mesopotamicus. Comp. Biochem. Physiol., 119: 991-997.

SAINT-PAUL, U., 1986, Potential for aquaculture of South American fishes: a review. Aquaculture, 54: 205-240.

SAINT-PAUL, U. \& BERNARDINO, G., 1988, Behavioural and ecomorphological responses of the neotropical pacu Piaractus mesopotamicus (Teleostei, Serrasalmidae) to oxygen-deficient waters. Exp. Biol. (Berlin), 48: 19-26.

SAINT-PAUL, U. \& SOARES, M. G., 1987, Diurnal distribution and behavioral responses of fishes to extreme hypoxia in na Amazon floodplain lake. Environ. Biol. Fishes, 20(2): 91-104.

SEVERI, W., 1991, Aspectos morfométricos e estruturais das brânquias de pacu, Piaractus mesopotamicus Holmberg, 1887 (Osteichthyes, Serrasalmidae). MSc Dissertation, PPG/ERN-UFSCar, 137p.

SEVERI, W., RANTIN, F. T. \& FERNANDES, M. N., 1997, Respiratory gill surface of the serrasalmid fish, Piaractus mesopotamicus. J. Fish Biol., 50: 127-136.

WEITZMAN, S. H., 1962, The osteology of Brycon meeki, a generalized characid fish, with an osteological definition of the family. Stanford Ichthyol. Bull., 8(1): 1-77. 